\title{
Outstanding Performance of Recently Released Linseed (Linum usitatissimum L.) Variety (Yadanno) and Other Linseed Lines in South Eastern Highlands of Ethiopia
}

\author{
Abebe Delesa Ararsa* Adane Choferie Chobe \\ Kulumsa Agricultural Research Center, P.O. Box 489, Asella, Ethiopia
}

\begin{abstract}
Yadanno is a common name for the linseed variety developed through hybridization and continuous selections using pedigree method. Yadanno was selected, developed and released by Kulumsa Agricultural Research Center for Arsi and West Arsi Zones and similar agro-ecologies of linseed growing areas of Ethiopia. Specifically, it was tested at Kulumsa, Bekoji, Asasa and Kofele for three years (2010/11 to 2012/13) and verified in 2014/15 at listed locations for 2016 official release. As a result, Yadanno consistently produced better mean seed and oil yields than the standard check (Kulumsa-1) and the local check over three years. Likewise, it proved to be resistant to wilt (Fusarium oxysporum f.sp. lini), powdery mildew (Oidium sp.) and pasmo (Septoria linicola) diseases. The results of the multi-location trials revealed that Yadanno was superior in seed and oil yields performance across years and locations. Besides, it is stable variety based upon different stability parameters.
\end{abstract}

Keywords: Edible Oil; Yadanno; Linseed; Variety registration

DOI: $10.7176 / \mathrm{JBAH} / 9-7-05$

Publication date: April $30^{\text {th }} 2019$

\section{INTRODUCTION}

Oil crops occupy third position following cereal and pulse crops in the agricultural economy of Ethiopia. Among oil crops linseed (Linum usitatissimum L.) is one of the ancient oilseeds cultivated for oil, food and fiber (Lay and Dybing, 1989; Nozkova, et al., 2016). Ethiopia is considered the secondary center of diversity and the $5^{\text {th }}$ major producer of linseed in the world after Canada, China, United States and India (Adugna, 2007), later on she became the $7^{\text {th }}$ major producer (FAOSTAT, 2017). Linseed is an annual and self-pollinated crop. Among oil crops linseed is the third important commodity next to sesame (Sesamum indicum L.) and noug (Guizotia abyssinica Cass.) in Ethiopia. But, it is the second and the first important oil crop in Oromia Regional State and Arsi Zone, respectively (CSA, 2017). During 2015/16 cropping season, 746,581 subsistence farmers allocated $85,415.67$ hectares of land for linseed production and produced 88,551 tons of linseed with an average yield of $1.04 \mathrm{t} / \mathrm{ha}$ (CSA, 2016). It occupies $10 \%$ of the total area cultivated for oilseeds with $11.3 \%$ of the total annual oilseeds production in the country. Earlier time area of linseed was increased from 142,899 hectares (ha) in $2003 / 04$ to 180,873 ha in 2008/09. In the same years, its production and average yield were also increased from 0.77 to 1.56 million quintals and from 541 to $863 \mathrm{~kg}$ ha-1, respectively. However, area and production of linseed dramatically decreased by $125 \%$ and $78 \%$ when we compare data of last eight years data (CSA, 2009; CSA 2017), nevertheless its productivity improved by $27 \%$. The realized reductions could be attributed mainly to: inherent low productivity of the crop, market volatility, consistent tax exempted edible oil importation like palm oil, lack of international collaboration on the crop improvement and development efforts, lack of germplasms exchange, limited government budget support, limited extension support, less suitability of the crop for mechanized operations, consistent market price increase for cereal and pulse crops specially for wheat and faba bean, and better availability of mechanized and pesticides technologies and services for competent commodities like bread wheat.

Linseed was widely cultivated in higher elevations of Ethiopia where frost was a threat for other crops including other oilseeds (Getinet and Nigussie, 1997). It is an important pre-cursor crop for cereal, pulse and potato crops in South Eastern Highlands of Ethiopia (Abebe and Adane, 2015). Typically, linseed consists of approximately $40 \%$ fat, $28 \%$ dietary fiber, $21 \%$ protein, $4 \%$ ash, and $6 \%$ carbohydrates (Vaisey-Genser and Morris, 2010). Linseed has wide and incredible uses: it is a source of food, feed, fiber, oil, medicine, and industrial raw material and export commodity. Linseed cake is rich in microelements, vitamins, dietary cellulose, proteins (up to 38\%) (Altai, 2010). Linseed has long history of cultivation by smallholder farmers, exclusively for its oil in the traditional agriculture of Ethiopia (Hiruy and Nigussie, 1988). The crop performs best in altitudes ranging from 2200 to 2800 meters above sea level (m. a. s. 1.). Linseed grows well within temperature ranges of 10 to $30^{\circ} \mathrm{C}$; but it performs best between 21 to $22^{\circ} \mathrm{C}$. Optimum soils for linseed are well drained but moisture retentive and medium to heavy textured such as clay loams and silty clays. Linseed will not perform well on soils with $\mathrm{pH}$ less than 5 and above 7 and is sensitive to soil salinity (Adugna, 2007), water logging or heavy clay soils (Jacobsz and van der Merwe, 2010) and seed bed conditions (Alexopoulou and Christou, 2011). It is widely cultivated in the high elevations area of Arsi, Bale, Shewa, Gojam, Gonder, Wollo and Wellega 
(Getinet and Nigussie, 1997).

Linseed oil is suitable for human consumption, and is used as a nutritional supplement. It is rich in omega-3 fatty acids, especially alpha-linolenic acid (C18:3) that is beneficial for heart disease, breast cancer, prostate cancer, colon diseases, inflammatory bowel disease, arthritis and a variety of other health conditions. It also contains a group of chemicals called lignans that play a significant role in the prevention of cancer (Budwing, 1994). The meal, which remains after oil extraction, is a valuable feed to animals as a protein supplement (Getinet and Nigussie, 1997). There is also a growing demand in the world market for linseed due to its numerous health benefits, especially in Europe (Wijnands et al., 2007). However, opportunities for oilseeds export are not fully exploited yet because of low productivity, inadequate quality, improper post-harvest handling, poor infrastructure and poor market information.

The Ethiopian edible oil sector consists of two groups of producers: the local, small-scale processors $(>1000)$ and a few medium and large scale enterprises $(\sim 20)$. The entire sector produces approximately 20,000 tons of edible oil annually; while domestic demand is estimated at 200,000 tons. Consequently, Ethiopia imports up to 160,000 tons of edible oil annually and this figure is increasing every year (PPPO, 2009). The increase of import suggests a potentially large domestic market. Main edible oil imports are palm and soybean oils from Malaysia and Indonesia. Ethiopia imported 351 thousand MT of palm oil by expending 424 million US Dollar in 2015 (USDA, 2015). Substitution of these oils by domestic production is encouraged by high domestic prices. Export oil (like sesame and linseed) is hardly being produced locally, since the export price of seed is usually very attractive and sesame seed is hardly locally consumed (PPPO, 2009). It can be seen as a business opportunity to increase the local capacity to produce linseed and sesame oils for export, increasing added value, foreign exchange and employment opportunity. In order to improve the Ethiopian edible oil sector, the Government should create equal taxation system for both domestically produced and imported edible oils, undertake feasibility study for increased production of oilseeds, and develop good manufacturing practices for the Ethiopian mill sector.

Despite the wide values of linseed in terms of nutritional, industrial, and export earnings; productivity and production of linseed is certainly low, $1.094 \mathrm{t} / \mathrm{ha}$ (CSA, 2017) as compared to cereal and pulse crops. Currently, there is a huge shortage of edible oil in the country (PPPO, 2009). Hence, concerted research, development, promotion, infrastructure and policy intervention efforts are needed, at all levels, in order to reverse the current situations. This paper presents the overall performances of the recently developed and released linseed variety (Yadanno) with the aim to play a significant role in solving the chronic edible oil shortage in the country, and to exploit its linseed production and productivity capacity for domestic uses and export purposes.

\section{VARIETAL EVALUATION}

Yadanno (H31 X Belay-96-208) was derived through hybridization between Belay-96 and H31 (a promising selection obtained from Holetta Agricultural Research Center/HARC). After crossing, $\mathrm{F}$ generations $\left(\mathrm{F}_{2}\right.$ to $\left.\mathrm{F}_{5}\right)$ of linseed crosses had been screened on artificially developed wilt (Fusariumoxysporumf.sp. lini) sick plots in order to select and advance lines with good agronomic performances and diseases resistance. As Yadanno outperformed several linseed lines, previous varieties, selections and accessions in observation and preliminary yield trials, it was advanced to regional variety trial to be tested across representative locations over years in order to further test its overall performances. The linseed regional variety trial set II consisting 18 linseed lines along with the standard check (Kulumsa-1) and the local check was conducted at major linseed growing districts of Arsi and West Arsi Zones including Kulumsa (Tiyo District), Bekoji (Lemu \& Bilbillo District), Asasa (Gedab Asasa District) and Kofele (Kofele District) for three main growing seasons (2010/11 to 2012/13). In these locations, the altitude ranges from $2200 \mathrm{~m}$. a. s. 1. (Kulumsa) to $2780 \mathrm{~m}$. a. s. 1. (Bekoji), and average annual rainfall ranges from $620 \mathrm{~mm}$ in Asasa to $1100 \mathrm{~mm}$ in Bekoji. The genotypes were tested across four locations in RCB design with four replications. Plot size was six rows of $20 \mathrm{~cm}$ apart and $5 \mathrm{~m}$ long. A seed rate of $25 \mathrm{~kg}$ ha-1 and fertilizer rate of 23/23 kg ha-1 N/P2O5 was applied at planting at each location, except at Kulumsa where fertilizer was not applied to minimize lodging. Other recommended cultural practices were also applied. Necessary agronomic performances and disease reactions were recorded.

\section{AGRONOMIC AND MORPHOLOGICAL CHARACTERISTICS}

In an attempt to develop Yadanno, higher seed yield, oil content and resistance to major linseed diseases were important traits of consideration. Yadanno flowered within 82 days and matured within 155 days after emergence (Table 1). Yadanno and Kulumsa-1are similar in terms of maturity regime. Yadanno was highly uniform and its average height was $88 \mathrm{~cm}$, but Kulumsa-1 was $97 \mathrm{~cm}$ tall, implying better resistance of Yadanno to lodging. Both Yadanno and Kulumsa-1are brown and bold seeded. The average weight of 1000 -seeds was $6.4 \mathrm{~g}$ for Yadanno, which is greater by $14.3 \%$ and $25.5 \%$ better than that of Kulumsa- 1 and the local check, respectively (Table $2 \&$ 3). Yadanno is a variety suitable for rain-fed, low inputs and organic farming on different soil types as long as the $\mathrm{pH}$ value is within the range of 6.0 to 7.6. However, it is not suitable for water logged or poorly drained soils. 
A summary of agronomic and morphological characteristics of the variety are presented in Table 1.

Table 1. Agronomic and morphological characteristics of Yadanno linseed variety

Adaptation area

Altitude (m. a. s. 1.)

2000-2800

Rainfall (mm)

$600-1100$

Temperature $\left({ }^{\mathrm{O}} \mathrm{C}\right)$

Soil $\mathrm{pH}$

6.0-7.6

Fertilizer rate

$\mathrm{N}(\mathrm{kg}$ ha-1)

$\mathrm{P}_{2} \mathrm{O}_{5}$ (kg ha-1)

Planting date

Early to late June

Seed rate (kg ha-1)

Row planting ( $20 \mathrm{~cm}$ between rows)

Broadcasting

Days to flowering

Days to maturity

Plant height $(\mathrm{cm})$

Number of pods per plant

Seed color

brown

Weight of 1000 seeds $(\mathrm{g})$

6.4

Reaction to major diseases

$<1.0$ (Resistant)

Oil content (\%)

39.1

Seed yield (kg ha-1) at research stations

2246

Seed yield (kg ha-1) on farmers' fields

Year of release

2015

Breeder/Maintainer

Kulumsa Agri. Research Center

\section{YIELD PERFORMANCE}

Considering the overall seed yields, Yadanno (H31 X Belay-96-208) produced better seed yield (2246 kg/ha) than the standard check Kulumsa-1(1772 kg/ha) across locations (Table $2 \& 3)$. This variety consistently performed better than the checks over three years. Yadanno was $26.7 \%$ high yielder than the standard check (Kulumsa-1) and $44.5 \%$ high yielder than the local check. It had $30 \%$ oil yield and $2.4 \%$ oil content advantage over Kulumsa-1. Likewise, it had 55\% oil yield and $7.1 \%$ oil content advantage over the local check. It was highly uniform with strong stalk and resistant to lodging and showed noble competence with different weed species. 
Table 2. Mean agronomic performance and diseases reaction of 20 linseed genotypes tested in four locations in Arsi and West Arsi Zones in the years, 2010/11-2012/13

\begin{tabular}{|c|c|c|c|c|c|c|c|c|c|c|c|}
\hline \multirow[b]{2}{*}{ Plot } & \multirow[b]{2}{*}{ Treatments } & \multicolumn{2}{|c|}{ Days to } & \multicolumn{3}{|c|}{ Diseases (0-5 scale) } & \multirow{2}{*}{$\begin{array}{l}\text { Plant } \\
\text { height } \\
\text { (cm) }\end{array}$} & \multirow[b]{2}{*}{$\begin{array}{c}\text { TSW } \\
\text { (g) }\end{array}$} & \multirow[b]{2}{*}{$\begin{array}{c}\text { SY } \\
\text { (kg/ha) }\end{array}$} & \multirow[b]{2}{*}{$\begin{array}{c}\text { OC } \\
(\%)\end{array}$} & \multirow[b]{2}{*}{$\begin{array}{c}\text { OY } \\
\text { (kg/ha }\end{array}$} \\
\hline & & Flower & Mature & $\begin{array}{l}\text { P. } \\
\text { mildew }\end{array}$ & Pasmo & Wilt & & & & & \\
\hline 1 & H31 X Belay-96-194 & 77 & 155 & 0.4 & 0.4 & 0.4 & 89 & 6.6 & 2226 & 38.7 & 861 \\
\hline 2 & H31 X Belay-96-159 & 79 & 154 & 0.4 & 0.4 & 0.4 & 88 & 6.6 & 2053 & 39.1 & 803 \\
\hline 3 & H31 X Belay-96-18 & 82 & 157 & 0.4 & 0.2 & 0.5 & 90 & 6.4 & 1920 & 39.1 & 751 \\
\hline 4 & H31 X Belay-96-208 & 82 & 155 & 0.5 & 0.7 & 0.5 & 88 & 6.4 & 2246 & 39.1 & 878 \\
\hline 5 & H31 X Belay-96-216 & 80 & 155 & 0.5 & 0.7 & 0.4 & 90 & 6.3 & 1882 & 38.0 & 715 \\
\hline 6 & H31 X Belay-96-146 & 82 & 157 & 0.5 & 0.3 & 0.4 & 90 & 6.2 & 2134 & 39.1 & 834 \\
\hline 7 & H31 X Belay-96-215 & 79 & 155 & 0.4 & 0.2 & 0.4 & 91 & 6.7 & 2044 & 38.4 & 785 \\
\hline 8 & H31 X Belay-96-204 & 79 & 155 & 0.3 & 0.3 & 0.4 & 89 & 6.5 & 2084 & 37.6 & 784 \\
\hline 9 & H31 X Belay-96-210 & 82 & 156 & 0.5 & 0.4 & 0.5 & 92 & 6.2 & 1825 & 38.0 & 694 \\
\hline 10 & Tolle X Chilallo-112 & 81 & 155 & 0.6 & 0.5 & 0.4 & 95 & 6.5 & 1968 & 38.1 & 750 \\
\hline 11 & H31 X Belay-96-201 & 80 & 156 & 0.5 & 0.3 & 0.5 & 92 & 6.4 & 1862 & 38.0 & 708 \\
\hline 12 & H31 X Belay-96-198 & 85 & 156 & 0.5 & 0.3 & 0.4 & 93 & 6.2 & 1975 & 38.0 & 751 \\
\hline 13 & H31 X Belay-96-236 & 78 & 154 & 0.7 & 0.8 & 0.3 & 84 & 6.3 & 2087 & 37.6 & 785 \\
\hline 14 & H31 X Belay-96-127 & 82 & 157 & 0.4 & 0.3 & 0.5 & 87 & 6.6 & 2018 & 38.5 & 777 \\
\hline 15 & H31 X Belay-96-50 & 81 & 158 & 0.4 & 0.4 & 0.4 & 88 & 6.5 & 2021 & 37.9 & 766 \\
\hline 16 & H31 X Belay-96-234 & 80 & 156 & 0.5 & 0.3 & 0.6 & 88 & 6.7 & 1916 & 39.1 & 749 \\
\hline 17 & H31 X Belay-96-73 & 79 & 154 & 0.4 & 0.3 & 0.5 & 91 & 6.6 & 2111 & 38.8 & 819 \\
\hline 18 & H31 X Belay-96-141 & 80 & 154 & 0.4 & 0.2 & 0.4 & 91 & 6.5 & 2007 & 38.8 & 779 \\
\hline 19 & Kulumsa-1 & 88 & 156 & 0.4 & 0.4 & 0.6 & 97 & 5.6 & 1772 & 38.2 & 677 \\
\hline \multirow[t]{4}{*}{20} & Local check & 88 & 158 & 1.1 & 0.9 & 0.7 & 86 & 5.1 & 1554 & 36.5 & 567 \\
\hline & Mean & 81 & 156 & 0.5 & 0.4 & 0.5 & 90 & 6.3 & 1985 & 38.3 & 761 \\
\hline & $\operatorname{LSD}(0.05)$ & 1.18 & 1.52 & 0.14 & 0.17 & 0.2 & 2.33 & 0.21 & 167.8 & & \\
\hline & $\mathrm{CV}(\%)$ & 2.2 & 1.6 & 39.0 & 67.9 & 65.1 & 5.3 & 0.1 & 14.8 & & \\
\hline
\end{tabular}

Where, $P$. Mildew = Powdery mildew; TSW = 1000 seeds weight; SY = Seed yield; OC = Oil content; OY = Oil yield; $L S D=$ Least significant difference; $C V=$ Coefficient of variation

Table 3. Summary of pooled mean seed and oil yields, other data and diseases reaction of Yadanno and the checks across years and locations

\begin{tabular}{|c|c|c|c|c|c|c|c|c|c|c|c|}
\hline Plot & Treatments & DF & DM & $\begin{array}{l}\text { PM } \\
(0-5)\end{array}$ & $\begin{array}{c}\text { Pasmo } \\
(0-5)\end{array}$ & $\begin{array}{l}\text { Wilt } \\
(0-5)\end{array}$ & $\begin{array}{l}\mathrm{PH} \\
(\mathrm{cm})\end{array}$ & $\begin{array}{c}\text { TSW } \\
(\mathrm{g})\end{array}$ & $\begin{array}{c}\text { SY } \\
(\mathrm{kg} / \mathrm{ha})\end{array}$ & $\begin{array}{l}\mathrm{OC} \\
(\%)\end{array}$ & $\begin{array}{c}\text { OY } \\
(\mathrm{kg} / \mathrm{ha})\end{array}$ \\
\hline 1 & Yadanno & 82 & 155 & 0.5 & 0.7 & 0.5 & 88 & 6.4 & 2246 & 39.1 & 878 \\
\hline 2 & Kulumsa-1 & 88 & 156 & 0.4 & 0.4 & 0.6 & 97 & 5.6 & 1772 & 38.2 & 677 \\
\hline 3 & Local check & 88 & 158 & 1.1 & 0.9 & 0.7 & 86 & 5.1 & 1554 & 36.5 & 567 \\
\hline
\end{tabular}

seeds weight; $S Y=$ Seed yield; $O C=$ Oil content; $O Y=$ Oil yield

\section{STABILITY PERFORMANCE}

Yield stability in 18 lines of linseed was studied for three years (2010/11 to 2012/13) at four locations (Kulumsa, Bekojji, Asasa and Kofele) using different stability parameters such as (bi) the regression coefficient (Finlay and Wilkinson, 1963), (S2di) deviation from regression (Eberhart and Russel, 1966), ecovalence (Wricke, 1962), Shukla stability variance (Shukla, 1972), $C V=$ coefficient of variation (Francis and Kannenberg, 1978) and a superiority measure (Lin and Binns, 1988) as shown on Table 4. The stability of varieties was defined by high mean seed yield, regression coefficient $(b i=1.0)$ and deviations from regression $(\mathrm{S} 2 \mathrm{di}=0)$. Besides, low $\mathrm{CV}$, ecovalence, Shukla stability variance, superiority measure reveal that a variety is stable across tested environments.

The results of the study showed that Yadanno and Kulumsa-1 were stable linseed variety based upon different stability parameters (Table 4). Likewise, Yadanno was the best variety in terms of mean seed and oil yields. 
Table 4. Summary of overall yield (kg/ha) and joint regression and other stability parameters of 20 linseed genotypes evaluated in South Eastern Ethiopia in 12 environments, 2010/11-2012/13

\begin{tabular}{|c|c|c|c|c|c|c|c|}
\hline GEN & Mean & $\begin{array}{l}\text { Francis } \\
\text { CV }(\%)\end{array}$ & $\begin{array}{l}\text { Eberhart\&Russell } \\
\text { Bi }\end{array}$ & S2di & $\begin{array}{l}\text { Shuckla } \\
\text { ri2 }\end{array}$ & $\begin{array}{l}\text { Wricke'sEcovalence } \\
\text { Wi }\end{array}$ & $\begin{array}{l}\text { Superiority Measure } \\
\text { Pi }\end{array}$ \\
\hline 1 & 2226.156 & 22.0622 & 0.822 & 37042.72 & 63793.34 & 413745.2 & 35648.49 \\
\hline 10 & 1968.375 & 22.795 & 0.8253 & -11275.1 & 17414.73 & 121560 & 129216.4 \\
\hline 11 & 1861.5 & 26.1594 & 0.8773 & 1324.041 & 24560.22 & 166576.6 & 179976.1 \\
\hline 12 & 1975.406 & 31.8844 & 1.1005 & 41862.19 & 61606.68 & 399969.3 & 131338.9 \\
\hline 13 & 2086.906 & 31.8603 & 1.2289 & -3881.95 & 31331.92 & 209238.3 & 79660.32 \\
\hline 14 & 2018.438 & 35.7419 & 1.325 & 6641.041 & 58065.95 & 377662.7 & 109476.9 \\
\hline 15 & 2021.313 & 27.9357 & 1.0529 & -15174.9 & 4992.89 & 43302.42 & 101498.5 \\
\hline 16 & 1915.625 & 28.4956 & 0.9034 & 56979.74 & 75766.61 & 489176.9 & 199868.8 \\
\hline 17 & 2110.844 & 24.3763 & 0.9037 & 18040.16 & 38662.11 & 255418.5 & 82696.09 \\
\hline 18 & 2006.594 & 26.6583 & 0.9928 & -12763.1 & 6426.7 & 52335.42 & 104530.6 \\
\hline 19 & 1772.375 & 32.8563 & 1.064 & 733.9087 & 20550.98 & 141318.4 & 241439.4 \\
\hline 2 & 2053.469 & 27.4423 & 1.017 & 7813.128 & 26097.91 & 176264 & 83157.88 \\
\hline 20 & 1554.25 & 36.1901 & 1.0178 & 5930.064 & 24313.03 & 165019.3 & 406856 \\
\hline 3 & 1920.156 & 26.1703 & 0.8873 & 13412.86 & 35328.09 & 234414.2 & 145824 \\
\hline 4 & 2245.656 & 23.3553 & 0.9255 & 16884.08 & 36387.49 & 241088.4 & 25596.1 \\
\hline 5 & 1882.313 & 29.9379 & 1.0017 & 18037.39 & 35745.07 & 237041.2 & 169375.1 \\
\hline 6 & 2133.906 & 30.7775 & 1.1971 & 9071.356 & 39405.09 & 260099.3 & 64090.39 \\
\hline 7 & 2043.656 & 30.1471 & 1.1351 & -3677.24 & 20801.76 & 142898.3 & 103498.5 \\
\hline 8 & 2084.344 & 23.8659 & 0.8907 & 5502.218 & 27556.06 & 185450.4 & 76993.66 \\
\hline 9 & 1824.938 & 25.3948 & 0.832 & 777.9094 & 28176.71 & 189360.5 & 203829.9 \\
\hline
\end{tabular}

Where, GEN = the 20 linseed genotypes evaluated, Mean = average yield of the 20 linseed genotypes, $B i=$ regression coefficient, $S 2 d i=$ deviation from regression (Eberhart and Russell 1966),

$C V=$ coefficient of variation (Francis and Kannenberg, 1978), ri2 = Shukla stability variance (Shukla 1972), Wi = ecovalence (Wricke, 1962) and $\mathrm{Pi}=$ superiority measure (Lin and Binns, 1988).

\section{DISEASE REACTION}

On the standard rating scale of 0-5, 0 being highly resistant, and 5 highly susceptible, Yadanno scored mean of 0.5, 0.5 and 0.7 for wilt (Fusariumoxysporium), powdery mildew (Oidium sp.) and pasmo (Septoria linicola) diseases, respectively (Table 2), indicating that the variety is resistant to major diseases of linseed. The resistance reaction of the variety could be integrated with other disease management methods such as crop rotation, managing infested debris, and fungicide seed treatments for remarkable results.

\section{QUALITY ANALYSIS}

Typically, linseed consists of approximately $40 \%$ fat, $28 \%$ dietary fiber, $21 \%$ protein, $4 \%$ ash and $6 \%$ carbohydrates such as sugars, phenolic acids, lignans, and hemi-cellulose (Vaisey-Genser and Morris, 2010). Linseed is rich in polyunsaturated fatty acids, particularly alpha-linolenic acid (ALA), the essential omega-3 fatty acid, and linoleic acid (LA), the essential omega- 6 fatty acid. These two polyunsaturated fatty acids are essential for humans-that is, they must be obtained from the fats and oils in foods because our bodies cannot make them. The omega-3 fatty acids have many biological effects that make them useful in preventing and managing chronic conditions such as type 2 diabetes, kidney disease, rheumatoid arthritis, high blood pressure, coronary heart disease, stroke and certain types of cancer (Connor, 2000). The composition of linseed can vary with genetics, growing environment, seed processing and method of analysis (Daun, et al., 2003). The protein content of the seed decreases as the oil content increases (Daun and Declercq, 1994). The oil content of linseed can be altered through traditional breeding methods, and it is affected by geography. Linseed requires moderate to cool temperatures and adequate moisture during the growing season for optimum seed yield and quality. Good yield can be achieved with a temperature range of $10-30{ }^{\circ} \mathrm{C}$, and a mid-day relative humidity of $60-70 \%$, and a rainfall of 150-200 mm distributed over the growing periods. Extensive scientific research over the past few decades has revealed numerous nutritional benefits of linseed due primarily to its fat, lignan, dietary fiber, and protein contents.

In the present study, the results of laboratory tests (Table $2 \& 3$ ) indicated that Yadanno contained 39.1\% oil content and it had 30\% oil yield and 2.4\% oil content advantages over Kulumsa-1. Likewise, it had 55\% oil yield and 7.1\% oil content advantages over the local check. Besides, Yadanno had $14.3 \%$ and 25.5\% more 1000 seeds weight than Kulumsa-1(the standard check) and the local check, respectively. Furthermore, Yadanno is also rich in essential fatty acids, lignan, fiber and protein. Hence, Yadanno has better health, industrial, nutritional and feed values.

\section{CONCLUSIONS}

Yadanno was the best yielding linseed variety. It is stable in seed yield performance over locations and years. It 
was resistant to major diseases of linseed that prevailed in the growing areas. Yadanno produced higher seed and oil yields and contained better oil content. Farmers also preferred the variety for its overall superior performance over the existing local variety, which is manifested by high uniformity, tall plant height, firm stalk, better pods load and number of branches per plant. Likewise, the variety has better industrial, non-industrial and nutritional values. Hence, Yadanno was verified and officially released for large scale production in Arsi, West Arsi Zones and similar agro-ecologies of Ethiopia.

\section{ACKNOWLEDGEMENTS}

The Ethiopian Institute of Agricultural Research offered the financial support to develop and release the variety. Kulumsa Agricultural Research Center Management Bodies, Technologies Multiplication and Farm Management Department Team are duly acknowledged for smooth implementation of trials over years and locations. The authors would like to acknowledge, specifically, Mr. Shemelis Mebrate, Mr. Solomon Atnafu and Mrs. Tizita Mekonin for their assistance in field data collection and management over years. The authors also extend their special thanks to the Highland Oil Crops Research Program of Holetta Agricultural Research Center for their assistance in analysis of oil content.

\section{REFERENCES}

Abebe D. and Adane C. 2015. Response of Linseed (Linum usitatissimum L.) To Seed Rates and Seeding Methods in South-Eastern Highlands of Ethiopia. Journal of Biology, Agriculture and Healthcare. Vol.5, No.13.

Adugna, W. 2007.Linseed (Linum usitatissimum L.).In: van der Vossen, H.A.M. and Mkamilo, G.S. (eds.). Vegetable oils and fats, Plant Resources of Tropical Africa (PROTA) no. 14, PROTA foundation, Wageningen, the Netherlands. pp. 108-115.

Alexopoulou, E. and M. Christou. 2011. Crops Industry: Oil crops that can be produced in EU27. CRES-Center for Renewable Energy Sources. 100pp.

Altai F. 2010. Flax Seed Cake. Scientific and Production Association 'Altai Flax' LLC. Russia.

Budwig, J. 1994. Linseed and Linseed Oil. http://www.numarkharmacist.com/hn/Supp/Flaxseed.htm. Accessed on $08 / 04 / 2008$.

Connor, W.E. 2000.Importance of n-3 fatty acids in health and disease.The American Journal of Clinical Nutrition 71: 171-175.

CSA (Central Statistical Agency of Ethiopia). 2016. Agricultural sample survey report on area and production of crops. Stat. Bul. Vol. 1. No. 278.

CSA (Central Statistical Agency of Ethiopia). 2017. Agricultural sample survey report on area and production of crops. Stat. Bul. Vol. 1. No. 584.

CSA (Central Statistical Authority). 2009. Agricultural sample survey report on area and production of crops. Stat. Bul. Vol. 1. No. 446.CSA., Addis Ababa, Ethiopia.

CSA (Central Statistical Authority). 2004. Agricultural samples survey 2003/04. CSA. Addis Ababa, Ethiopia.

Daun, J.K., Barthet, V.J., Chornick, T.L. and Duguid, S. 2003. Structure, composition, and variety development of linseed.In: Thompson, L.U. and Cunnane, S.C. (eds.). Linseed in Human Nutrition, 2nd ed., AOCS Press, Champaign, IL, pp. 1-40.

Daun, J.K. and Declercq, R.D. 1994. Sixty years of Canadian flaxseed quality surveys at the Grain Research Laboratory. Proc. Flax Inst. 55: 192-200.

Eberhart, S.A. and Russel, W.A. 1966.Stability parameters for comparing varieties. Crop Science 6: 36-40.

FAOSTAT. 2017. Food and Agriculture of the United Nations. (http://faostat.fao.org) (Accessed on April 2, 2019).

Finlay, K.W. and G.N. Wilkinson. 1963. The analysis of adaptation in a plant breeding program. Aust. J. of Agric. Res. 14: 742-754.

Francis, T.R. and L. W. Kannenberg. 1978. Yield stability studies in short season maize 1. A descriptive method for grouping genotypes. Can. J. Plant Sci., 58: 1029-1034

Getinet, A. and Nigussie, A. 1997. Highland oil crops: A three decade Research experience in Ethiopia. Research Report No. 30. Institute of Agric. Res. Addis Ababa, Ethiopia.

Hiruy, B. and Nigussie, A. 1988. Verification of improved linseed production practices on farmer's field. In: Proceedings of the 4th Oil Crops Network Workshop. Njoro, Kenya, 25-29 January, 1988. IDRC MR 205e. Ottawa, Canada.

Jacobsz, M. J. and W.J.C. van der Merwe. 2010. Production guidelines for flax (Linum usitatissimum L.). Department of Agriculture, Forestry and Fisheries, Republic of South Africa.

Lay, C.L. and Dybing, C.D. 1989. Linseed.In: Robbelin, G., Downey, R.K. and Ashri, A. (eds.). Oil Crops of the World.McGrow-Hill, New York.

Lin, C. S. and M. R. Binns. 1988. A superiority measure of cultivar performance for cultivar $\times$ location data. 
Canadian Journal of Plant Science, 68: 193 - 198.

Nozkova, J., P. Martin, B. Marie, B. Nina, T. Eva, P. Elezaveta and B. Jan. 2016. Descriptor list of flax (Linum usitatissimum L.). Slovak University of Agriculture. ISBN978-80-552-1484-9.

Pinthus, M.J. 1973. Estimates of genotypic value: a proposed method. Euphytica 22: 345-351.

PPPO (Public Private Partnership on Oilseeds). 2009. Improving the competitiveness of the Ethiopian edible oil sector-policy brief. http://eposspea.org/. (Accessed on June, 26, 2011).

Shukla, G. K., 1972. Some statistical aspects of partitioning genotype-environmental components of variability. Heredity $29: 237$ - 245

USDA. 2015. United State Department of Agriculture, Foreign Agricultural Service. (http://fas.usda.org) (Accessed on April 4, 2019).

Vaisey-Genser, M. and Morris, D.H. 2010. Flaxseed: Health Nutrition and Functionality. Flax Council of Canada, Winnipeg, Manitoba.

Wijnands, J., Biersteker, J. and Hiel, R. 2007. Oilseeds business opportunities in Ethiopia. Ministry of Agric., Nature \& Food Quality, Hague, the Netherlands.

Wricke, G.1962. On a method of understanding the biological diversity in field Research. Z. Pfl.-Zücht, 47: 92 146 